\title{
O ESPAÇO PÚBLICO E O DIREITO À CULTURA: ESTUDO SOBRE OS EVENTOS MUSICAIS SEXTA ÀS SEIS E FESTIVAL DE MÚSICA DE PONTA GROSSA (PR)
}

\author{
Adriana Aparecida de Andrade \\ Universidade Estadual de Ponta Grossa (UEPG) \\ andrade.aaa3@gmail.com \\ Leonel Brizolla Monastirsky \\ Universidade Estadual de Ponta Grossa (UEPG) \\ leonel@uepg.br
}

\begin{abstract}
RESUMO
A pesquisa teve como objetivo geral compreender em que medida os eventos musicais (Sexta às Seis e Festival de Música de Ponta Grossa) constituem as experiências dos indivíduos (público, músicos e organizadores) no espaço público de Ponta Grossa, e quais medidas e ações o poder público toma em relação a promoção e organização desses eventos. Essa pesquisa também analisou as dinâmicas musicais de promoção ao direito à cidade e à cultura, assim como buscou compreender a relação indivíduo e espaço público. A pesquisa caracteriza-se como qualitativa, utilizando-se de entrevistas semiestruturadas com músicos e membros da Fundação Municipal de Cultura com o auxílio de tópico guia e ponto de saturação e também questionários online. Identifica-se os eventos musicais de suma importância para o acesso à cultura na cidade, como possibilitam a participação de vários segmentos sociais, gêneros, etnias e gostos musicais, possibilitam que artistas locais tenham a oportunidade de mostrar o seu trabalho, possibilitam aos indivíduos o contato direto com artistas reconhecidos no cenário musical nacional, e são importantes por incentivar a utilização e valorização dos espaços públicos através de atividades culturais.
\end{abstract}

Palavras-chave: Espaço público. Experiências musicais. Música. Projeto cultural.

\section{PUBLIC SPACE AND THE RIGHT TO CULTURE: STUDY ON MUSICAL EVENTS SEXTA ÀS SEIS AND FESTIVAL DE MÚSICA DE PONTA GROSSA}

(PR)

\begin{abstract}
This research had as its main objective to understand to what extent the musical events (Sexta às Seis and the city music festival, Festival de Música de Ponta Grossa) constitute the individuals' experience (audience, musicians and organizers) in the public space in Ponta Grossa and what are the measures and actions that the public administration takes related to the promotion and organization of these events. This research also analyzed the musical dynamics promoting the right to the city and to the culture, as well as it sought to understand the relation between individual and space. The research characterizes as qualitative methodology, with semi structured interviews with musicians and members of the city cultural foundation (Fundação Municipal de Cultura) within the help of a guidance document and data saturation, and also an online questionnaire. The musical events extremely important to the city cultural access, since they allow the attendance of various social segments, genders, ethnicities, and musical taste; they allow that the local artists have the opportunity of showing their work; they allow the individuals to have close contact with well-known artists of the national music scene; and they are important to encourage the use and appreciation of the public spaces through cultural activities.
\end{abstract}

Keywords: Public space. Musical experiences. Music. Cultural project.

\section{INTRODUÇÃO}

Durante várias sextas-feiras do ano, muitas pessoas (jovens, adolescentes, crianças e idosos) se reúnem no Complexo Ambiental Governador Manoel Ribas (Ponta Grossa - PR), a partir das dezoito horas, para apreciar a música de artistas locais - os estilos variam desde o heavy metal ao samba. Pessoas solitárias, grupos de amigos e famílias dançam, cantam, espalham-se pelo gramado; bebem, fumam, se divertem naquele que é um dos mais importantes eventos culturais gratuitos e em espaço

$\begin{array}{llllll}\text { Caminhos de Geografia } & \text { Uberlândia-MG } & \text { v. 22, n. } 83 & \text { out./2021 } & \text { p. 31-46 } & \text { Página } 31\end{array}$


púbico da cidade: o Projeto Sexta às Seis - que teve início em 1990 e atualmente faz parte das atividades culturais permanentes da cidade.

Outro evento que se faz presente na agenda dos apreciadores de música na cidade é o Festival de Música de Ponta Grossa, que em 2019 efetivou a sua décima primeira edição e que tem em seu cronograma atividades voltadas a todo tipo de público, desde recitais, oficinas e shows ao vivo. O Festival acontece em teatros, ruas, terminais de transporte coletivo e parques, enfim, apresentações em espaços públicos. Assim como o "Sexta", o Festival de Música tem público diversificado e nos últimos anos tem mobilizado muitas pessoas a apreciarem a música ao vivo em espaços públicos, principalmente no Parque Ambiental - o mais utilizado em função da centralidade e aproximação com o principal terminal viário da cidade.

A escolha em pesquisar esses dois eventos citados se dá pela inquietação de buscar compreender como se dá todo o processo de existência e organização dessas atividades culturais: a motivação que move tantas pessoas e, ao mesmo tempo, como o poder Público percebe e organiza esses eventos culturais. A premissa é que o sucesso dos eventos não é apenas pela música, já que ela se encontra fácil e gratuitamente em diversas plataformas online; não é apenas pelo espaço público, já que em dias que não há os eventos esses espaços são utilizados para outros fins não culturais; e não é apenas pela gratuidade, já que existem na cidade outras atividades culturais gratuitas.

Acredita-se que as motivações são diversas, mas a principal seria o conjunto que o compõe o fenômeno: 'música ao vivo de forma gratuita no espaço público promovida pelo poder público através de políticas culturais', acredita-se que quando um desses requisitos falta o fenômeno acaba não acontecendo. Sendo assim, essa pesquisa buscará demonstrar que esses requisitos se complementam e fazem do 'Sexta' e do 'Festival' dois dos eventos musicais mais procurados na cidade.

A pesquisa ${ }^{1}$ teve como objetivo principal compreender em que medida projetos e eventos musicais estruturam as experiências dos sujeitos (público, músicos e organizadores) no espaço público de Ponta Grossa (PR). E como objetivos específicos: averiguar as ações do poder público em relação a promoção e organização desses eventos; investigar a relação indivíduo e espaço público durante as sonoridades; analisar as dinâmicas musicais de promoção ao direito à cultura e por fim, compreender as experiências dos sujeitos no espaço público de Ponta Grossa, através da música em eventos musicais.

Em relação aos métodos utilizados para realização dessa pesquisa, optou-se pelas entrevistas (membros da Fundação Municipal de Cultura) e aplicação de questionários online ${ }^{2}$ (músicos e público).

Optou-se pelo questionário online, para saber sobre a experiência do público e músicos, depois da tentativa de entrevistar pessoas na plateia do Festival de Música - uma ação que se mostrou ineficiente devido ao alto volume do som.

Essa é uma pesquisa qualitativa pautada pelo método de saturação (BAUER e GASKELL, 2003), desse modo não depende necessariamente de números para validar o resultado, a partir do momento em que as respostas dos entrevistados e respondentes começam a saturar ela é finalizada, entretanto, houve a necessidade de obtenção de dados estatísticos para complementar o trabalho.

A pesquisa também conta com a técnica da 'observação participante'3. De acordo com Lakatos e Marconi (2003), na observação participante o pesquisador participa da realidade do grupo ou comunidade estudada, incorpora-se e confunde-se com os mesmos e participa de todas as atividades. Optou-se por esse tipo de abordagem por compreender que o indivíduo, quando é entrevistado ou responde a um questionário pode omitir detalhes e reflexões importantes. É fundamental transitar entre as pessoas, perceber as reações, sentir o clima, conversar. Muitos entrevistados não ponderam de forma mais ampla sobre os eventos e sobre a sua participação neles; consideram o evento como algo dado - uma ordem dada.

\footnotetext{
${ }_{1}^{1}$ Pesquisa elaborada durante os anos de 2018 a 2020, reflexões incluídas na dissertação.

2 Criado no Drive, serviço de armazenamento em servidores externos conectados através da internet (nuvem). Disponibiliza entre outras aplicações, a criação de formulários on-line, que possibilitam a coleta e gravação de informações através da conta de e-mail do Google.

${ }^{3}$ Durante as observações buscou-se analisar a dinâmica de apropriação do espaço público durante os eventos, buscou-se similaridades e diversidades nas ações dos participantes, bem como, perceber atividades desempenhadas pelos envolvidos que não foram descritas nas respostas dos questionários.
}
Caminhos de Geografia
Uberlândia-MG
v. 22, n. 83
out./2021
p. $31-46$
Página 32 


\section{A PROCURA DAS EXPERIÊNCIAS DAS APRESENTAÇÕES MUSICAIS AO VIVO}

A proposta dessa pesquisa considera pensar que a música sofre mudanças no modo de sua produção, reprodução e consumo. A experiência em ouvi-la ao vivo é completamente diferente de ouvi-la através de gravações, pois a música ao vivo envolve vários sentimentos e entre os mais eminentes estão o de sentir a energia de quem executa e de quem a aprecia. Com o advento da tecnologia e os meios de produção em série, ela passou a ser gravada e disponibilizada em maior número através de vinis, fitas cassetes, CD's e atualmente MP3, sendo disponibilizada gratuitamente através de plataformas online. É importante ressaltar a transformação da música para compreender como nos dias atuais, eventos, concertos, festivais e shows vem atraindo tantas pessoas para apreciar a música ao vivo.

Herschmann (2010) afirma que a indústria da música vem passando por uma transição em função da emergência da cultura digital ou era digital, o que faz com que as pessoas, neste novo contexto, busquem algo a mais, não bastando apenas ouvir a música, mas participar de toda experiência proporcionada durante as apresentações ao vivo - exatamente o que sentiam as pessoas quando se tinha apenas as apresentações ao vivo.

Mesmo com as mudanças estruturais que ocorrem na música e com a indústria da música, as pessoas ainda buscam os festivais, concertos, eventos e lugares com música ao vivo, em busca de algo que a tecnologia não proporciona, ou pelo menos não de forma completa, que seria a experiência do contato com outros indivíduos, o estar junto, sentir-se parte do coletivo: "eis a revolução a que assistimos: só existimos em relação, em comunhão com os outros", o que garante a solidez do vínculo social é a partilha das emoções vividas e não mais o ideal racional do contrato social (MAFFESOLI, 2007, p. 48).

A experiência, em vários setores, é palavra-chave; é através dela que se pode explicar a relação que cada um estabelece com o grupo, a natureza, o espaço e a vida em geral. Emergindo dos aspectos afetuosos, emocionais e de sintonia com o outro, as experiências "ganham evidência quando os indivíduos encontram na coletividade similitudes na atribuição de valores a cada fenômeno vivido. Assim, por meio das experiências e dos valores atribuídos, os grupos humanos organizam-se, creditando significados que estão nos distintos campos da vida, expressos nas diferentes formas simbólicas" (TORRES, 2014, p. 36).

Talvez alguns dos motivos pelos quais as pessoas participam de eventos musicais seja a busca por uma experiência efêmera, um pluralismo cultural, o encontro com o diverso e diferente. No caso de Ponta Grossa, eventos como o "Sexta às Seis" e o Festival de Música, que ocorrem em espaços públicos e de forma inteiramente gratuita, o encontro de diferentes é notório, pois pessoas que possuem interesses em apreciar apresentações musicais se dirigem para o espaço público no centro da cidade sem saber o que irão encontrar (além daquilo que faz parte da programação): quais pessoas estarão presentes, que relações serão formadas, isso também acontece com os músicos; há sempre uma expectativa de experiência nova proporcionada pela música ao vivo.

Os músicos participantes dos eventos afirmam haver diferenças, principalmente pelo envolvimento corporal, afetivo e sensorial ao qual o indivíduo se envolve durante apresentações ao vivo. De acordo com Alain, da Banda Jerimoon, "a música ao vivo vai além do simples ouvir. A vibração do som, as luzes, as performances dos artistas e as pessoas em volta tornam a experiência multissensorial". Já para Kevin, da banda Astronautas do Passado, a música está estritamente relacionada com a subjetividade: "a música ao vivo deixa a experiência mais evidente". Os músicos dão destaque ao fato da tecnologia, mesmo atualmente muito desenvolvida, ainda não conseguir suprir a vontade de 'viver o momento', que há com a música ao vivo: "quando você escuta a música ao vivo, você não apenas sente a música, os músicos, você sente as pessoas e a beleza que existe na arte produzida por elas de uma forma que você também participa como parte de um todo" afirma Ronaldo da Banda Streides.

O público participante que respondeu ao questionário afirma que há enorme diferença em ouvir a música gravada e a música ao vivo, exatamente pela sensação de prazer que as apresentações ao vivo proporcionam, comentam sobre a interação entre artista e público e também que o local de ocorrência é um forte influenciador de boas sensações. O respondente $2^{4}$ afirma: "a música ao vivo tem muito mais emoção, o artista está 'dando o sangue' ali pra tocar o melhor que ele pode pra quem está ouvindo e isso é muito emocionante!". Já o respondente 13 explica que a música gravada tem mais relação com particularidade de quem está ouvindo, é um momento íntimo de cada pessoa: "é

${ }^{4}$ Os indivíduos que responderam ao questionário online são identificados por números.

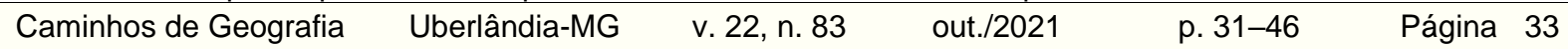


emocionante, uma sensação bem diferente de ouvir música ao vivo do que a gravada, pois a gravada é mais íntima, um momento pessoal". Já o respondente 9 explica que a música ao vivo proporciona conhecer os artistas pessoalmente, e também as suas verdadeiras habilidades, diferente da música gravada a qual se tem o apoio da tecnologia, para esse respondente cada apresentação é única e esse é o grande diferencial.

Além disso, pode-se pensar que os eventos musicais vêm não apenas como meio de fortalecimento dos relacionamentos entre as pessoas presentes, mas como forma de o poder local gerir e manter espaços de direitos dos cidadãos por meio de projetos culturais, tratando das desavenças entre os indivíduos, suas diferenças culturais e sociais, bem como proporcionar um espaço comum a todos.

\section{ESPAÇOS PÚBLICOS: DIVERSIDADE, EQUIDADE E DIREITO À CULTURA E À CIDADE.}

Embora seja papel do poder público local criar, gerir e manter políticas culturais locais, a afirmação de Serpa (2007, p. 142) indica que o processo é ainda mais complexo, pois "a cultura é um motivo de conflito de interesses nas sociedades contemporâneas, um conflito pela sua definição, pelo seu controle, pelos benefícios que assegura", ou seja, envolve relações de poder, desse modo, seria errôneo e raso pensar que todas as pessoas possuem o mesmo privilégio de participar de atividades promovidas através de políticas culturais. Esses eventos, projetos e manifestações, por mais atrativos que sejam, não chegam a toda população, tanto pela questão econômica quanto pela localização, pode-se indicar também o fato de não ser o habitus ${ }^{5}$ de muitas pessoas frequentarem eventos musicais.

Sendo assim, pensar em políticas públicas culturais requer pensar na reinvenção do cotidiano; no estímulo da diversidade, da criatividade, da transformação social, o que pressupõe pensar em direitos. Para isso, o poder público deve apresentar uma estratégia cultural, ou um planejamento cultural; esse planejamento deve relacionar os objetivos, as atividades, os recursos e resultados esperados, e sobretudo, deve contar com a participação popular, o que "significa, dar voz e visibilidade para os diferentes agentes e grupos que produzem e assimilam (apreendem) cultura, reconhecendo sua diversidade e suas diferenças. É preciso desconstruir a hierarquia das diferenças que transforma o que é diverso em desigual" (SERPA, 2007, p. 143), já que o direito à cultura está previsto na Constituição Federal de 1988, no art. 215 que afirma, "o Estado garantirá a todos o pleno exercício dos direitos culturais e acesso às fontes da cultura nacional, e apoiará e incentivará a valorização e a difusão das manifestações culturais".

No município de Ponta Grossa, a atuação do poder público no âmbito cultural, dá-se por meio da Fundação Municipal de Cultura e que tem por finalidade planejar, promover, coordenar, executar e acompanhar as ações culturais do Poder Público Municipal no domínio da produção, memória e difusão, bem como fomentar as manifestações artístico-culturais dos diversos segmentos da sociedade ${ }^{6}$. Dentre as inúmeras competências desse órgão, destaca-se: I) a responsabilidade juntamente ao Conselho Municipal de Política Cultural pela elaboração das políticas culturais do município; II) incentivar a participação da comunidade em favor de programas e projetos culturais, buscando a expansão das atividades culturais na sociedade pontagrossense; III) convocar e coordenar a realização da Conferência Municipal de Cultura; IV) gerir fundos e contas, e aplicar recursos relativos ao desenvolvimento de suas atividades.

Pode-se indicar como grande propulsor da cultura na cidade o Plano Municipal de Cultura ${ }^{7}$ (LEI № 13.026, de 18/12/2017), que estabelece as normativas para a realização dos programas e projetos culturais que podem ser realizados tanto por meio de incentivo de iniciativas privadas quanto da iniciativa do próprio poder público Os investimentos destinados a esses projetos e programas podem

${ }^{5}$ Considera-se o habitus conforme Setton (2002), que elabora uma reflexão através dos estudos de Bourdieu (1992), afirmando que o habitus é construído no processo de socialização, processo esse sempre inacabado pois ocorre durante a vida do indivíduo, é estruturado nos meios sociais, e estruturante de ações e representações, "é um instrumento conceptual que auxilia a apreender uma certa homogeneidade nas disposições, nos gostos e preferências de grupos e/ou indivíduos produtos de uma mesma trajetória social" (Setton, 2002, p. 65).

${ }^{6}$ De acordo com o site oficial da cidade de Ponta Grossa, disponível em: http://www.pontagrossa.pr.gov.br/fmc

7 Define políticas públicas por dez anos, assegurando o estabelecimento de um sistema de gestão pública e participativa e o acompanhamento e avaliação das políticas culturais, proteção e promoção do patrimônio e da diversidade cultural, acesso a produção e fruição da cultura em todo o município, além da inserção da cultura em modelos sustentáveis de desenvolvimento socioeconômico (LEI 13.026/2017).
Caminhos de Geografia
Uberlândia-MG
v. 22, n. 83
out./2021
p. $31-46$
Página 34 
ser de iniciativas privadas, mas também, através do Fundo Municipal de Cultura - conta bancária onde ficam registradas as verbas públicas destinadas a cultura da cidade durante o ano.

De acordo com Eduardo Godoy (Diretor de Cultura da Fundação Municipal de Cultura de Ponta Grossa), os eventos estudados (Festival de Música e "Sexta às Seis") estão inseridos no "guardachuva' do Plano Municipal de Cultura da cidade. Eduardo explica que:

\begin{abstract}
Eles atendem bastante itens do nosso Plano Municipal de Cultura, falamos que está sob o guarda-chuva do Plano Municipal de Cultura desde o final de 2017, os eventos têm que atender no mínimo uma parte dos itens que demandam do Plano, exemplo: a democratização do acesso à cultura é um dos principais já que os dois eventos ocorrerem gratuitamente, o Sexta às Seis por acontecer no espaço central próximo ao terminal urbano aberto ao público, o Festival de Música em espaços também centrais abertos ao público mas também nas comunidades, instituições, presídios, enfim, atendendo grande parte da população em diversos bairros; a questão do auxílio do apoio ao fazer artístico, no Sexta às Seis é quase $100 \%$ de bandas da cidade, tirando os especiais, ele é voltado para os músicos da cidade, o Festival de Música boa parte também é voltado para os artistas locais; atendimento a crianças e adolescentes; o incremento ao turismo cultural que é um dos itens que acaba trazendo principalmente no Festival de Música que vem pessoas de fora da cidade para curtir o festival não só de contratação mas para participar do festival; os principais itens são esses. (Entrevistado Eduardo Godoy, 2019).
\end{abstract}

Para os músicos e o público é importante que o Poder Público amplie as atividades culturais na cidade, eles afirmam que eventos musicais como o Sexta às Seis e o Festival de Música de Ponta Grossa são boas opções de investimento de verba pública, que projetos assim dão visibilidade aos artistas locais, movimentam a cena cultural da cidade, bem como aumenta as vendas de comerciantes locais. De acordo com o respondente 2 "tanto o Festival quanto ao 'Sexta às Seis' são os eventos mais acessíveis à comunidade em geral e ao mesmo tempo são os eventos mais 'alternativos' promovidos pela fundação/prefeitura". Já o respondente 3 afirma que é obrigação da prefeitura promover o acesso à cultura "toda cidade deve garantir o acesso à cultura aos seus moradores, acredito que além de mantê-los, a prefeitura deveria fornecer mais eventos culturais para que as pessoas frequentem e se tornem mais cultas".

Diante disso, é possível afirmar que a dinâmica de criação, promoção, circulação e participação cultural da cidade são processos importantes que só se concretizam através da boa relação entre o Poder Público, os secretários de políticas culturais, artistas locais, verba pública ou privada - através de agentes patrocinadores - e principalmente a população. Por fim, ressalta-se que a escolha dos locais de realização dos eventos se dá em função da acessibilidade da população, pois se faz necessário levar cultura a espaços também destinados a outras atividades, afirmação que vai ao encontro das respostas dos músicos e público participante.

A partir da entrevista com o poder público nota-se a primazia pela utilização dos espaços públicos como locais de ocorrência dos eventos musicais da cidade. Primeiramente, entende-se que para um espaço ser considerado público não deve haver restrições em relação a sua acessibilidade, este deve ser organizado pelo poder público e é um direito elementar à própria cidade ${ }^{8}$ (LEFEBVRE, 2001), pois permite a criação de relações significativas entre os indivíduos e a cidade, produzindo aprendizado, acesso à cultura, aventura individual e coletiva. Quando se fala em espaço público, é preciso ter em mente que se trata da diversidade, equidade de direitos através das normas e leis de conduta, como afirmado por Gomes (2002, p. 162) "poderíamos dizer que o espaço público é o lugar das indiferenças, ou seja, onde as afinidades sociais, os jogos de prestígio, as diferenças, quaisquer que sejam, devem se submeter às regras de civilidade".

\footnotetext{
${ }^{8}$ Henri Lefebvre (2001) em sua obra 'O direito à cidade', utilizada por estudiosos de diferentes áreas, traz uma abordagem para entender a cidade através dos direitos dos cidadãos e à vida urbana. Nessa obra o autor demostra o processo pelo qual a cidade passa através da industrialização, quando passou a ser vista e constituída como mercadoria, onde há a maior valorização de troca e não a de uso e que esse processo não é natural, pois existem frações de classes que dirigem e interveem nesse processo, produzindo uma cidade segregada. Lefebvre (2001) direciona os pesquisadores a pensar que os problemas sociais urbanos não devem ser reduzidos apenas às questões de espacialidades e planejamento urbano, mas, que os indivíduos são sujeitos ativos na concepção de cidade, de cidadania indo além do direito ao voto, mas, habitar a cidade com suas diferenças e particularidades sociais, culturais e políticas. O autor nos convida a refletir sobre uma cidade possibilitadora de encontros, confrontos das diferenças, da visitação e da habitação; conhecimentos e reconhecimentos recíprocos (inclusive no confronto ideológico e político) dos modos de viver e dos 'padrões' que coexistem nela; enfim, uma cidade que pode ser ouvida, lida, escrita, sentida e percebida.
}
Caminhos de Geografia
Uberlândia-MG
v. 22, n. 83
out./2021
p. $31-46$
Página 35 
Sendo assim, as pesquisas na geografia, devem nortear-se pela concretude dos espaços públicos, considerar as práticas e dinâmicas sociais que aí se desenvolvem, e também, é necessário relacionar as dimensões políticas, sociais e aspectos formais e estruturais desses espaços (SERPA, 2004).

Os objetos de estudo dessa pesquisa - "Sexta às Seis" e Festival de Música - sempre ocorreram em espaços públicos de Ponta Grossa, propiciando durante os anos de ocorrência o fortalecimento da afirmativa de Sobarzo (2006) que analisa os espaços públicos como possibilitadores de encontros de pessoas desconhecidas, que mesmo quando possuem ideias, gostos e ideologias diferentes, não constituem nisso impedimento de uma boa relação social, do mesmo modo, esses espaços são "produtos", já que são resultados de uma construção social ligada à necessidade de sociabilidade e, ao mesmo tempo, são "produtores" de novas relações construindo novos papéis como espaços por si mesmos (SOUZA, 2008, p. 16).

Serpa (2007) propõe analisar o espaço público considerando a forma e o conteúdo, buscando articular os aspectos que dão concretude a esses espaços e os aspectos mais subjetivos e abstratos, no caso, é necessário articular a disposição locacional em paralelo com as dinâmicas sociais (GOMES, 2002). Desse modo, é relevante pensar que o espaço público é um dos elementos que fazem e que dão vida à cidade, através das múltiplas manifestações, discursos, gestos, atividades, imagens, comportamentos, falas, itinerários, percursos e paradas, maneiras de particularizar e valorizar diferencialmente esse espaço, ou seja, são formas de ser no espaço.

Visto o importante papel que o espaço público desempenha na cidade, é necessário refletir sobre a função do poder público tanto na criação desses espaços, como em sua manutenção, já que "o espaço público muitas vezes é usado como um amortizador dos conflitos, como uma forma de iludir os indivíduos" (VALVERDE, 2007, p. 74), assim também, esse espaço reflete as tensões do processo de produção do espaço urbano, bem como reflete os múltiplos conflitos de interesses que, geralmente, se resumem como conflitos público-privado e também conflitos em detrimento de privilégios a uma minoria (LEFEBVRE, 2001).

Portanto, para que os indivíduos se sintam atraídos a movimentar, utilizar e apropriar-se dos espaços públicos, os mesmos devem estar em boas condições, bem estruturados, transparecer a pluralidade cultural e vitalidade da cidade. Consolidando esse compromisso por meio do poder público, evita-se que haja o abandono, que o espaço em questão se converta em terra de ninguém, não havendo regras de usos, e assim perder suas características fundamentais: a de terreno de convivência, associação social e encontro entre diferentes (GOMES, 2002).

Uma das formas de evitar o abandono dos espaços públicos seria através da apropriação, resultante do uso, pelas relações horizontais ${ }^{9}$, onde as pessoas constroem e são construídas, modificam e são modificadas, encontram e dão sentidos ao e no espaço público que se abre para infinitas possibilidades, uma delas seria a leitura do outro e daquilo que é diferente (SOBARZO, 2006). Essa apropriação pode levar ao sentimento de pertencimento e reconhecimento e adiante talvez, a uma mobilização social com a potencialidade de transformação da realidade. Além disso, a apropriação cotidiana dos espaços públicos pode ser considerada como "um primeiro estágio da articulação escalar com vistas à geração de processos de transformação e mudança social na escala da cidade" (SOBARZO, 2006, p. 108).

De acordo com os músicos que tocaram no "Sexta às Seis" (2019), os espaços públicos são essenciais para a sociedade tanto "socialmente como culturalmente" (Alain Barros, 2019); manter uma boa estrutura física com iluminação, segurança, projetos sociais, pois, de acordo com Kevin: "viver em sociedade não é só estudar e trabalhar, mas interagir com o outro, e os espaços públicos podem permitir isso, "[...] são importantes para o convívio em sociedade, para as expressões artísticas e para o lazer como forma de repouso e descanso".

Já para o público respondente do questionário, os espaços públicos são fundamentais para o desenvolvimento social, entretanto, muitos espaços públicos da cidade estão descuidados, principalmente os espaços públicos afastados da área central urbana. $O$ respondente 27 afirma que na gestão do atual prefeito os espaços públicos estão recebendo atenção especial: "está fazendo um

9 Termo utilizado por Milton Santos em seu livro A natureza do espaço: técnica e tempo, razão e emoção (1997, p. 227) "As horizontalidades são tanto o lugar da finalidade imposta de fora, de longe e de cima, quanto o da contra finalidade, localmente gerada. Elas são o teatro de um cotidiano conforme, mas não obrigatoriamente conformista, e, simultaneamente, o lugar da cegueira e da descoberta, da complacência e da revolta".
Caminhos de Geografia
Uberlândia-MG
v. 22, n. 83
out./2021
p. 31-46
Página 36 
bem danado para os espaços públicos, esses espaços são importantíssimos para integração social da cidade, permitindo momentos de lazer pra todas as classes sociais".

Com essas afirmações, considera-se que é por meio da utilização dos espaços públicos que se obtêm os aspectos marcantes da vida, ou parte dela, são esses espaços que carregam os sentidos da história das cidades e a expressão da diversidade de comportamentos, estilos e modos de vida, são "lugares de interação sócio espacial" (LOBODA, 2008, p. 64), ou seja, incluem "o afetivo, o imaginário, o sonho, o corpo e o prazer, que caracterizariam o homem como espontaneidade, como energia vital" (SERPA, 2007, p. 38).

O espaço público onde ocorrem os dois eventos estudados é o Complexo Ambiental Governador Manoel Ribas (figura 1), mais conhecido como Parque Ambiental que vem ao longo dos anos se tornando um dos espaços públicos mais utilizados para eventos culturais na cidade, exatamente por motivos de localização, estrutura e preferência da população.

Figura 1 - Localização do Complexo Ambiental Governador Manoel Ribas, Ponta Grossa-PR.

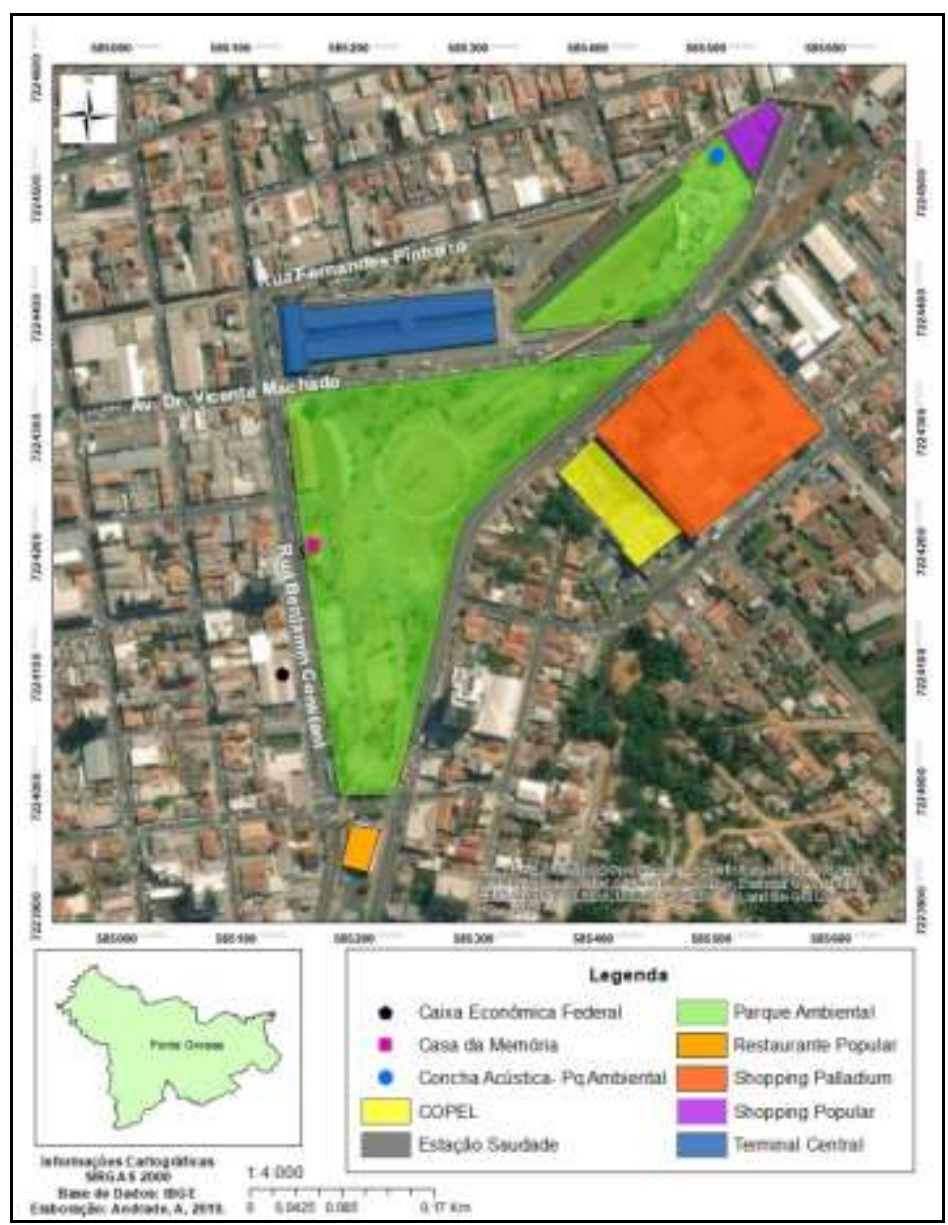

Fonte - A autora (2019)

À primeira vista, o Parque Ambiental - antigo Pátio da Ferrovia - apresenta boa estruturação: amplo, com várias árvores, bancos, pista de caminhada, academia ao ar livre, pista de skate e quadras de esportes, parque infantil, redários e gramado amplo. Pode-se dizer que o espaço é particularmente limpo, são responsáveis pela limpeza equipes contratadas pela Prefeitura Municipal, dessa forma a limpeza do local é feita diariamente e em todo o perímetro encontram-se lixeiras.

De acordo com Eduardo Godoy, havia muitas reclamações sobre o parque, as pessoas reclamavam em relação às áreas verdes, já que não existiam tantas árvores como agora e nem um gramado tão extenso. Com o passar dos anos, a prefeitura realizou ações de reestruturação do parque, entre elas a transformação em um parque realmente ambiental.

$\begin{array}{llllll}\text { Caminhos de Geografia } & \text { Uberlândia-MG } & \text { v. 22, n. } 83 & \text { out./2021 } & \text { p. 31-46 } & \text { Página } 37\end{array}$


Figura 2 - Diferentes espaços do Complexo Ambiental Governador Manoel Ribas.
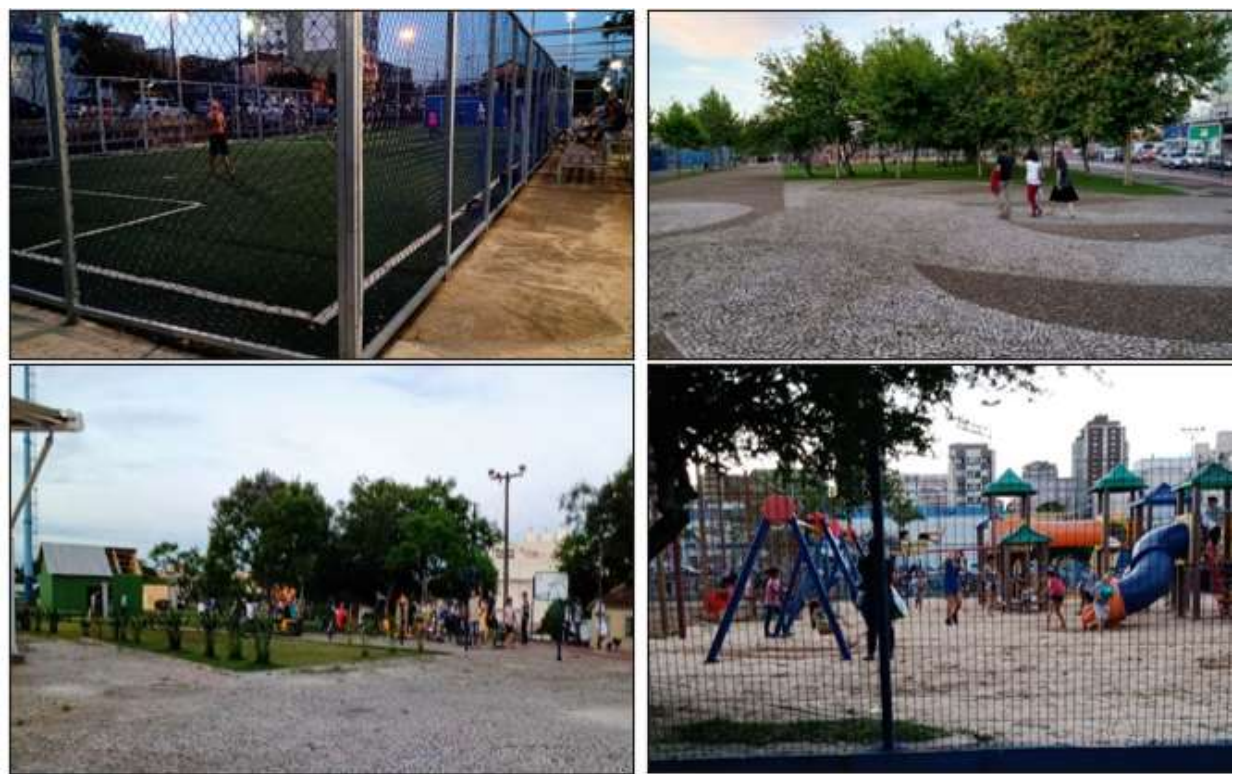

Fonte - A autora (2019).

O local pode ser considerado seguro, pois há um posto fixo da Policia Militar nesse espaço e durante alguns dias da semana há a presença de um posto móvel da Guarda Municipal. É um espaço muito movimentado durante o dia, com atividades bem diversificadas praticadas pelas pessoas que acessam esse local.

O fato desse espaço público ser tão bem aproveitado para diversos usos acontece porque as qualidades do ambiente são favoráveis para essa pluralidade, é quando as vantagens tanto físicas, psicológicas e sociais se sobrepõem às desvantagens, o que torna o ambiente agradável, com segurança, beleza e conforto (GEHL, 2006, apud DARODA, 2012). Essas características fazem desse local um espaço público bem-sucedido, pois é acessível, ativo, confortável e sociável.

\section{BREVE HISTÓRICO DOS OBJETOS DE ESTUDO: SEXTA ÀS SEIS E FESTIVAL DE MÚSICA DE PONTA GROSSA}

A cidade de Ponta Grossa possui em sua agenda cultural vários projetos ${ }^{10}$ e eventos oriundos de iniciativas públicas e privadas. Há uma dinâmica de elaboração envolvendo poder público, conselheiros, artistas e população em geral. Além das normativas de promoção e produção cultural, existem as escolhas de localização de realização desses projetos e eventos, que vêm nos últimos anos apresentando predileção aos espaços públicos da cidade, bem como escolas, associações de moradores, terminais viários e unidades de saúde ${ }^{11}$. Pode-se afirmar que estes eventos são responsáveis por movimentar a cena cultural da cidade envolvendo artistas, pesquisadores, poder público, apreciadores, comerciantes e empresários locais e outros setores.

O sucesso destes eventos depende de uma série de fatores: localização, premiação, estrutura, público alvo e etc. Em suma, pode-se afirmar que o histórico do 'Sexta às Seis' está estritamente relacionado com o fluxo de pessoas e acessibilidade, sempre ocorrendo em locais próximos a pontos de transporte coletivo urbano (SCHONHERR, 2017; ANDRADE, 2017). O Projeto Cultural "Sexta às Seis" teve início em 1990 (fotografia 3) e é uma iniciativa da Prefeitura Municipal de Ponta Grossa, por meio da Fundação Municipal de Cultura.

No início, as apresentações ocorriam na Concha Acústica da Praça Barão do Rio Branco (de 1990 a 1992), mas com a mudança de governo em 1993, o "Sexta" tem sua primeira parada, retornando em 2005, por um curto período de tempo até 2008 , na mesma praça, que era cercada por comércio, colégios, edifício residencial e igreja. Em decorrência do alto volume do som e do número de pessoas

${ }^{10}$ Festival Universitário da Canção (FUC), Festival Nacional de Teatro (FENATA) e München Fest.

${ }^{11}$ Locais escolhidos para realização de editais culturais lançados pela Fundação Municipal de Cultura de Ponta Grossa, disponível em: http://www.pontagrossa.pr.gov.br/cultura

$\begin{array}{llllll}\text { Caminhos de Geografia } & \text { Uberlândia-MG } & \text { v. 22, n. } 83 & \text { out./2021 } & \text { p. 31-46 } & \text { Página } 38\end{array}$


que paravam para assistir às apresentações, houve reclamações de moradores e frequentadores da igreja e dos colégios, junto à prefeitura, para que o local de ocorrência do evento fosse alterado. Sendo assim, o evento retorna apenas em 2011 e permanece até 2012 na Concha Acústica do Parque Ambiental ${ }^{12}$, mais tarde passou a ocorrer na gare da Estação Saudade - Estação Ferroviária Ponta Grossa - de 2014 a 2016. Atualmente, o local escolhido pela Fundação Municipal de Cultura é um palco montado, sempre às sextas-feiras, em frente à lanchonete, localizado próximo ao terminal central e ainda no espaço do Parque Ambiental da cidade.

Atualmente, o "Sexta" tem como principal objetivo o incentivo a músicos e bandas locais, oferecendo uma estrutura de palco profissional, divulgação da arte e cultura local, bem como, para as bandas e músicos selecionados via edital, a garantia de premiação. $O$ presidente da Fundação ${ }^{13}$, explica que para "o Sexta às Seis é feito um edital, as bandas se inscrevem, passam pelo processo de seleção com pessoas de reconhecida capacidade dentro da área musical -, e aí é feita a seleção das bandas". Ele explica ainda que o evento movimenta a produção musical na cidade por ser um projeto de periodicidade quinzenal e que de 2014 a 2019 já teve a inscrição de aproximadamente 170 bandas locais.

A visão do poder público em relação ao "Sexta às Seis" é que o evento é um marco cultural de música na cidade de Ponta Grossa, por dar a oportunidade aos músicos locais de mostrarem seus trabalhos e proporcionar a população conhecer o trabalho desses músicos.

Já o Festival de Música de Ponta Grossa tem um histórico mais diversificado. Deu início nas atividades no ano de 2009 e era voltado ao público da música erudita; em sua programação havia recitais e concertos de músicos e artistas que se destacavam em território nacional. Passou a ter novo formato em 2015, quando as apresentações passaram a ocorrer também no calçadão, na Concha Acústica e terminais de transportes. Entretanto, pode-se afirmar que a grande mudança ocorreu na $8^{a}$ edição no ano de 2016, buscando aproximar a população de diferentes estilos musicais desde o clássico ao popular.

A partir da $8^{a}$ edição, o Festival passa a contar com um palco aberto às "novas sonoridades" montado próximo à Estação Saudade e aberto ao público em geral, entretanto, algumas atividades ainda eram voltadas ao público da música erudita no Centro de Música, Centro de Cultura, Concha Acústica e no Teatro Ópera. De acordo com diretor do departamento de cultura de Ponta Grossa, o Festival ganha uma nova 'cara' a partir do Palco Novas Sonoridades, e ainda, que uma das grandes dificuldades na elaboração do Festival é encontrar bandas locais que façam shows inteiramente autorais.

Desde essa edição (2016), há um giro musical bem diversificado, artistas de várias regiões do Brasil passaram pelo palco do Festival, há multiplicidade de estilos, e, além da participação de músicos de fora, a prefeitura dá abertura para músicos locais apresentarem seus trabalhos ao público. Soma-se a isso a abertura de oportunidade às pessoas de diferentes idades participarem das oficinas e minicursos de música e instrumentos musicais durante o Festival. Além disso, acontece o giro cultural pela cidade, as apresentações ocorreram em asilos, escolas, Centro de Referência de Assistência Social (CRAS), penitenciárias, prefeitura, entre outros locais.

O Festival de Música e o "Sexta às Seis", ao longo dos anos, têm levado mais e mais pessoas aos espaços públicos de Ponta Grossa, demonstrando que a utilização desses espaços através de atividades culturais é boa aposta para movimentar a cidade e promover o direito à cultura e à cidade. De acordo com Eduardo Godoy, o retorno das pessoas em relação aos dois eventos é positivo, pois as pessoas criaram o habito de ir ao Parque Ambiental nas sextas-feiras mesmo quando não há eventos, bem como, nota-se a alegria e a satisfação dos participantes.

\section{PERFIL DOS ENVOLVIDOS NOS EVENTOS ESTUDADOS}

A partir das entrevistas e análises dos questionários foi possível identificar um perfil dos envolvidos nos eventos. Em relação ao número de respondentes do questionário, a prevalência é de homens, a idade dos participantes varia entre dezesseis anos e quarenta e cinco anos, entretanto, esse valor corresponde apenas aos respondentes do questionário, mas, através da observação participante, é notável a presença de crianças e também idosos. Já a idade dos músicos varia de dezenove a trinta e nove anos. O maior número de pessoas possui ensino médio completo, Em relação ao local de

12 Datas e informações citadas no site Cultura Plural, disponível em: https://culturaplural.sites.uepg.br/?p=1821

${ }^{13}$ Fernando Durante (2019).

Caminhos de Geografia

Uberlândia-MG

v. 22, n. 83

out./2021

p. $31-46$

Página 39 
moradia dos respondentes, percebe-se que o bairro com maior número de participantes durante os eventos é o bairro de Uvaranas, esse dado pode estar ligado ao fato do bairro de Uvaranas ser mais próximo ao centro, nesse caso seria de mais fácil acesso ao Parque Ambiental (bairro Centro). Mesmo assim, os eventos têm a participação de moradores de bairros mais longínquos como bairro Contorno, bairro Chapada e bairro Boa Vista, isso é demonstrado nas figuras 3 e 4 .

Figura 2 - Local de moradia dos participantes do Festival de Música de Ponta Grossa (2018 e 2019).

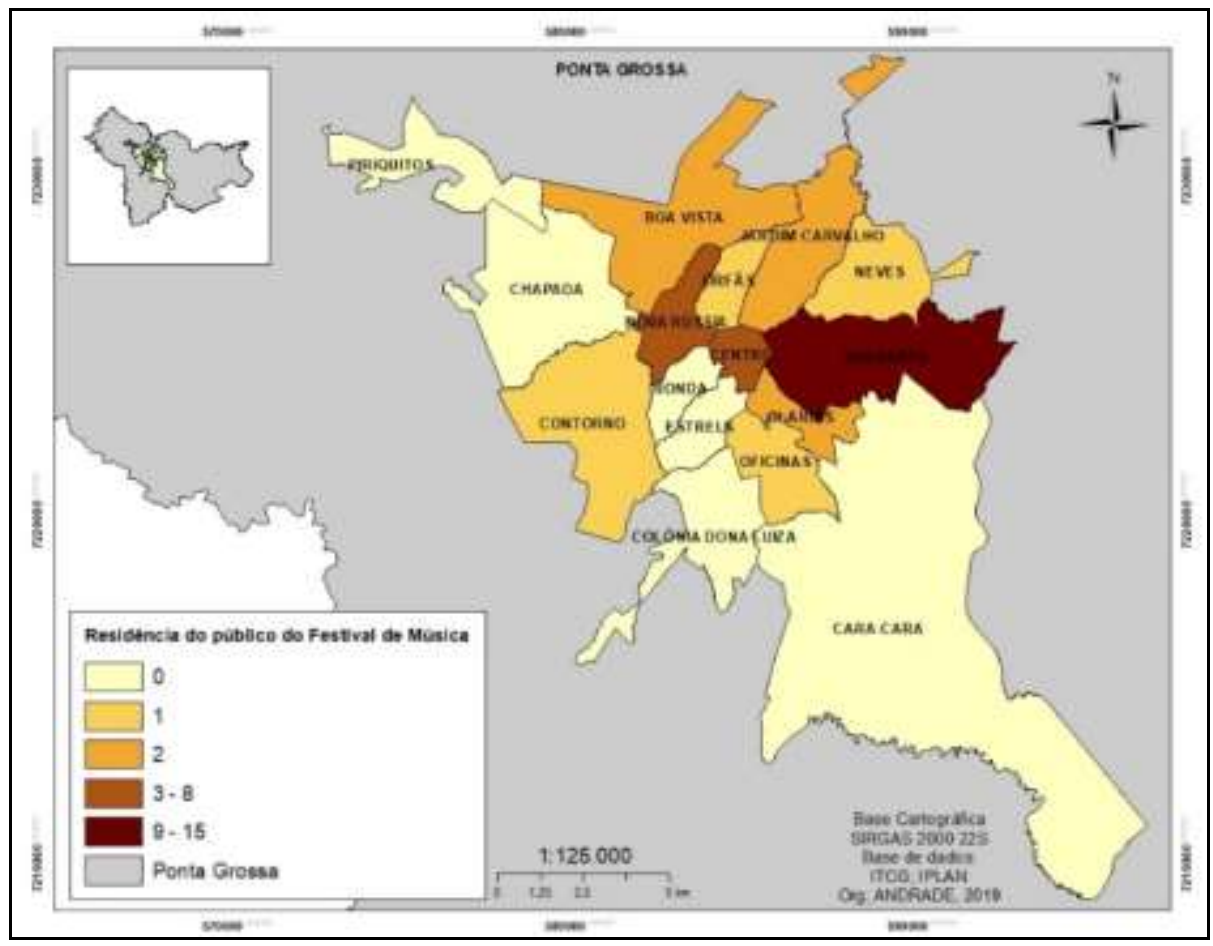

Fonte - A autora (2019).

Figura 3 - Local de moradia dos participantes do Sexta às Seis (2018 e 2019).

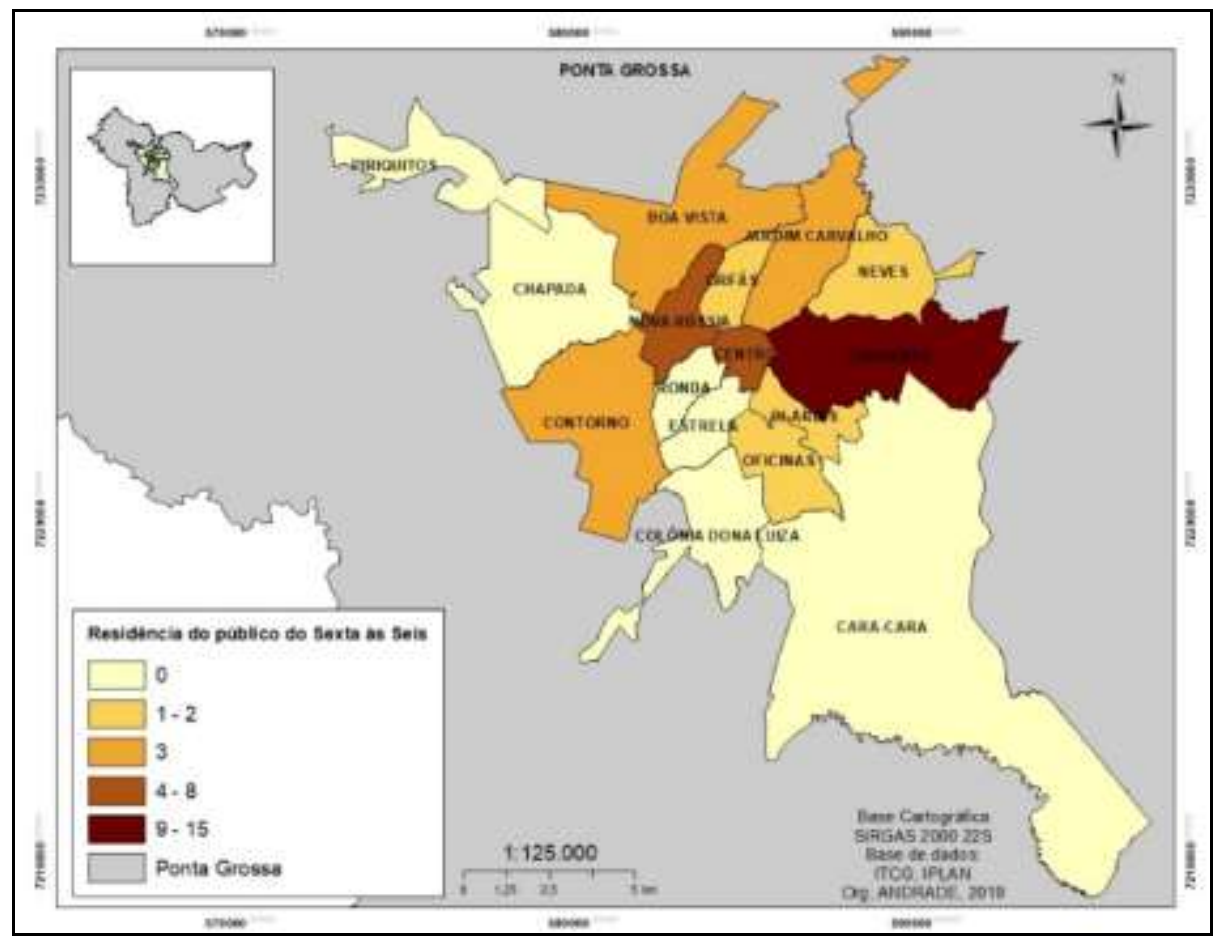

Fonte - A autora (2019). 
Sobre a renda dos participantes dos eventos o maior número (20 indivíduos) afirma possuir mensalmente a renda de mil a quase cinco mil reais, em seguida 12 indivíduos afirmam ter renda de até novecentos e noventa e nove reais, e o restante (11 indivíduos) afirma estar desempregado.

No caso dos músicos, buscou-se saber se possuíam outra profissão ou se a renda provém apenas da música. A maioria afirma ainda não conseguir ter como profissão principal a música, há administradores, açougueiros, programadores, cervejeiros artesanais, analistas de TI, entre outros.

A partir dessas informações, é inquestionável a diversidade dos indivíduos envolvidos no "Sexta às Seis" (fotografia 1) e Festival de Música (fotografia 2), diferentes idades, classes sociais, gostos musicais e etc, todos utilizando o mesmo espaço. São diferentes grupos que somam presença nos eventos, o grupo de amigos, familiares, organizadores, artistas de rua, músicos, estudantes, etc. Todos esses grupos interagem entre si e com o espaço.

Figura 5 - Palco Sexta às Seis, edição 2019.

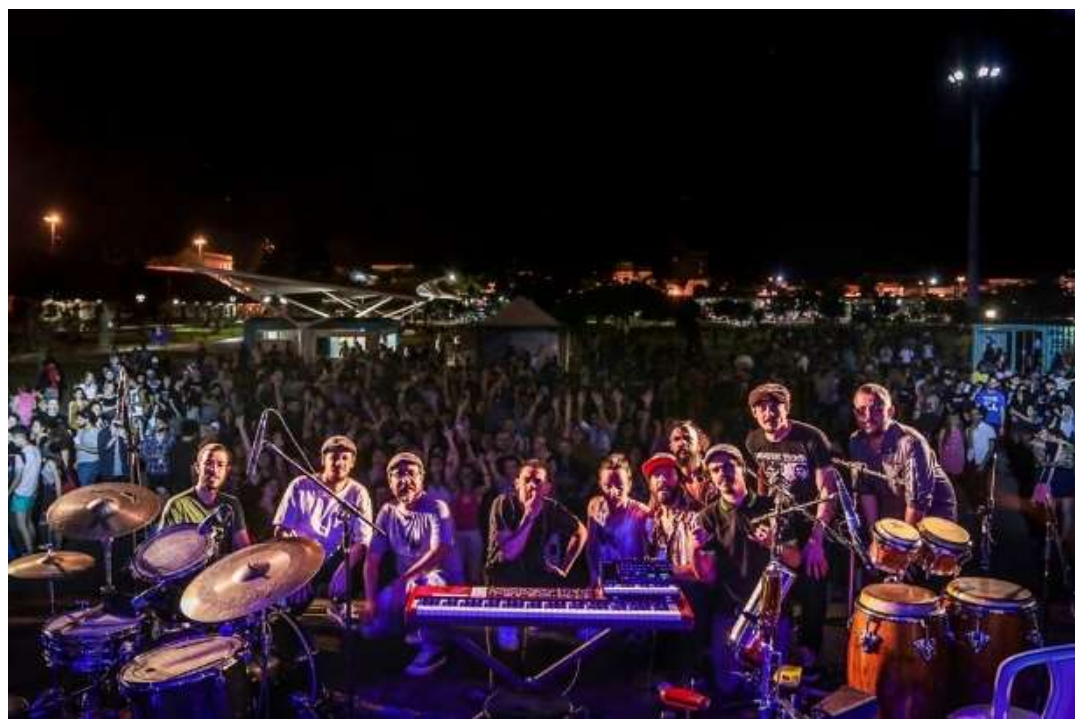

Fonte - BAZZI, M (2019).

Figura 6 - Palco Novas Sonoridades do Festival de Música de Ponta Grossa, edição 2018.

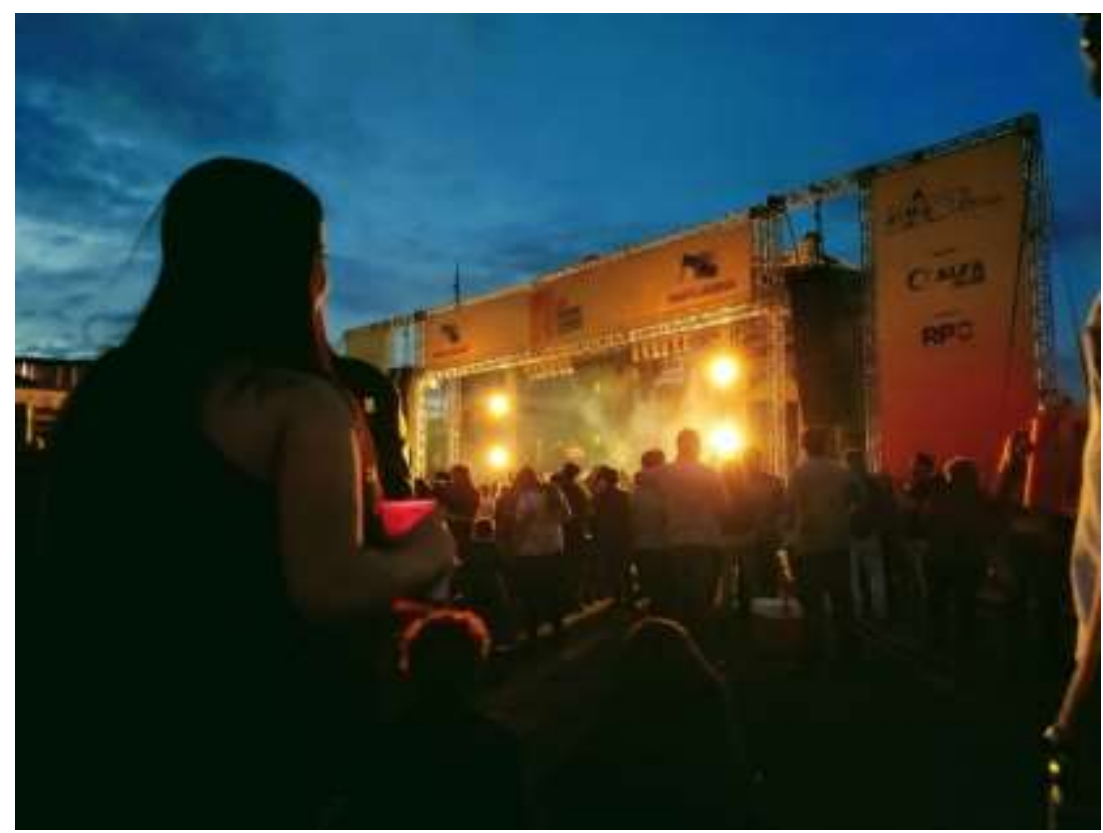

Fonte - A autora (2018).

$\begin{array}{llllll}\text { Caminhos de Geografia } & \text { Uberlândia-MG } & \text { v. 22, n. } 83 & \text { out./2021 } & \text { p. 31-46 } & \text { Página } 41\end{array}$


A dinâmica de espacialização do local muda em decorrência do tipo de música que toca, se a banda ou grupo musical é mais ou menos conhecido, e em decorrência das condições climáticas (ANDRADE, 2017). Em dias com temperaturas mais agradáveis, nota-se que as pessoas descansam e apreciam os shows sentados na grama espalhados pelo local, nos dias com temperaturas mais baixas - comum na Região Sul - as pessoas ficam mais próximas umas das outras, levam seus animais de estimação, comidas e bebidas para apreciar as apresentações.

\section{PERCEPÇÃO, CONCEPÇÃO E VIVÊNCIA DOS ENVOLVIDOS NO FENÔMENO}

Diante desse cenário, buscou-se através das concepcões lefebvrianas elaborar uma análise de como o espaço em questão passa a ser percebido, concebido e vivido pelos envolvidos nos eventos (poder público, público e músicos).

Lefebvre em sua obra intitulada La production de l'espace ${ }^{14}$, em 1974, produz uma teoria sobre a problemática do espaço. Para ele, era insuficiente definir o espaço a partir apenas da produção em sentido dos economistas (números, capital, quantias). Seu interesse seria o espaço vivido, vinculado à prática espacial, pois, para ele, o espaço não é apenas um receptáculo, no espaço se desdobram as estruturas econômicas, políticas e ideológicas. Sua teoria expõe o espaço como produto social, resultado das acões, relações e experiências sociais e fazendo parte delas, sendo suporte e também campo de ações sociais, é inacabado e continuamente produzido sofrendo interferências do e com o tempo, sendo o tempo elemento fundamental para descrição dos fatos ocorridos no espaço.

A base para compreender a teoria de Lefebvre (1991) é a assimilação de que a produção do espaço pode ser dividida em três dimensões ou processos dialeticamente interconectados, sendo fundamentalmente de igual valor: o espaço é ao mesmo tempo, percebido, concebido e vivido. Nenhuma dessas dimensões pode ser imaginada como a origem absoluta e, muitos menos, privilegiada. Pois, de acordo com o autor, é preciso ter a consciência que o espaço é inacabado e está sendo produzido temporalmente.

A seguir, no quadro 1, apresenta-se de forma sistemática como a concepção tríade de Lefebvre (1991) sobre o espaço poderia ser aplicada ao fenômeno estudado - eventos musicais no espaço público Complexo Ambiental Governador Manoel Ribas.

Quadro 1 - Tríade espacial baseada nos conceitos de Henri Lefebvre (1991).

\begin{tabular}{|c|c|c|c|c|}
\hline PERSPECTIVA & ESPAÇO & $\begin{array}{l}\text { CIRCUNSTÂNCIA DE } \\
\text { ABSTRAÇÃO }\end{array}$ & APLICAÇÃO & AÇÕES E RESULTADOS \\
\hline $\begin{array}{l}\text { Práticas } \\
\text { espaciais }\end{array}$ & $\begin{array}{l}\text { ESPAÇO } \\
\text { PERCEBIDO }\end{array}$ & $\begin{array}{l}\text { É aberto ao toque físico, } \\
\text { é o espaço material, } \\
\text { correspondente ao } \\
\text { mundo da interação tátil } \\
\text { e sensorial com a } \\
\text { matéria. }\end{array}$ & $\begin{array}{l}\text { Espaço onde } \\
\text { ocorre os } \\
\text { eventos - } \\
\text { Complexo } \\
\text { Ambiental Gov. } \\
\text { Manoel Ribas }\end{array}$ & $\begin{array}{l}\text { Locais para sentar, boa/má } \\
\text { estrutura, com/sem } \\
\text { arborização, } \\
\text { aberto/fechado... }\end{array}$ \\
\hline $\begin{array}{l}\text { Representação } \\
\text { do espaço }\end{array}$ & $\begin{array}{l}\text { ESPAÇO } \\
\text { CONCEBIDO }\end{array}$ & $\begin{array}{l}\text { É a junção de } \\
\text { elementos e formas } \\
\text { espaciais concebidas } \\
\text { pelos especialistas } \\
\text { (engenheiros, } \\
\text { arquitetos, políticos, } \\
\text { planejadores e } \\
\text { cientistas urbanos) que } \\
\text { criam signos e códigos } \\
\text { de ordenação que } \\
\text { fragmentam e } \\
\text { restringem o espaço, } \\
\text { formando o todo. }\end{array}$ & $\begin{array}{l}\text { Espaço } \\
\text { concebido e } \\
\text { planejado pelo } \\
\text { PODER } \\
\text { PÚBLICO }\end{array}$ & $\begin{array}{l}\text { Horário, local, datas } \\
\text { disponíveis, acesso/restrição } \\
\text { de público, } \\
\text { liberação/proibição de } \\
\text { produtos... }\end{array}$ \\
\hline $\begin{array}{l}\text { Espaços de } \\
\text { representação }\end{array}$ & $\begin{array}{l}\text { ESPAÇO } \\
\text { VIVIDO }\end{array}$ & $\begin{array}{l}\text { Apresentam } \\
\text { simbolismos complexos, } \\
\text { são uma parte } \\
\text { integrante de nosso } \\
\text { modo de viver no } \\
\text { mundo, espaço que a } \\
\text { imaginação tenta } \\
\text { modificar e apropriar. }\end{array}$ & $\begin{array}{l}\text { Espaço dos } \\
\text { MÚSICOS E } \\
\text { PÚBLICO }\end{array}$ & $\begin{array}{l}\text { Liberdade/dominação, } \\
\text { diversidade/homogeneidade, } \\
\text { amizades, encontros, } \\
\text { confrontos, afetos, } \\
\text { desafetos, alegrias, } \\
\text { tristezas, memórias, } \\
\text { sentimentos bons e ruins. }\end{array}$ \\
\hline
\end{tabular}

Elaboração - A autora (2019).

${ }^{14}$ Essa é a versão oficial da obra, entretanto, foi feita a leitura da obra traduzida por Doralice Barros Pereira e Sérgio Martins de 2006. 
O espaço material é onde se desenrolam as práticas espaciais, é aberto aos aspectos físicos sensoriais, nesse caso, seria o espaço do Parque Ambiental, onde as pessoas vão para apreciar as apresentações ao vivo, é esse espaço material que possibilitaria a convivência, as sensações e emoções dos envolvidos. O espaço concebido seria as representações e a forma organizacional do poder público sobre o espaço material criando ordens de conduta, normas de elaboração e especificando as formas de cada 'objeto' em determinado local, restringindo ou abrindo este local. O espaço vivido seria aquele no qual os indivíduos representam e são representados, vivenciando aquele espaço através de emoções, símbolos, imaginação, ou seja, envolve o estado psíquico dos indivíduos.

O espaço material do Parque Ambiental, como já mencionado, é aberto e possui uma estrutura física adaptada para as atividades propostas e realizadas por seus frequentadores. É percebido pelos indivíduos participantes dos eventos como um espaço agradável, propício para realizar eventos como - Festival e o "Sexta". Muitos indivíduos reconhecem as ações realizadas pelo poder público em tornar o ambiente mais verde e seguro, entretanto, alguns indivíduos têm a percepção de que poderia ser feito mais: plantar mais árvores, melhorar a segurança, colocar mais lixeiras, fazer mais eventos etc. O respondente 5 percebe o contexto em que o espaço do parque está envolvido e explica: "a história arquitetônica do parque é interessante, assim como as construções aos seus arredores, tais como, Estação Saudade e Estação Arte, ambos patrimônios culturais. Nos últimos anos o parque passou por uma revitalização o que deixou mais bonito, mais arborizado e, portanto, mais frequentado. Sendo um local de fácil acesso, propício para realização de tais eventos". Vários respondentes apresentam uma percepção mais simplória afirmando ser 'legal', 'bom', 'acessível', entre outros termos.

A percepção que os músicos têm em relação ao espaço material em que ocorrem os eventos está em concordância com a percepção do público. De acordo com eles, o espaço, além de todas as características já apontadas, é também um espaço que tem boa acústica por ser amplo e está sendo mais valorizado tanto pelos indivíduos, como pelo poder público.

A concepção do espaço do Festival de Música e do "Sexta às Seis", como elencado por Lefebvre, fica a cargo do poder público - Fundação Municipal de Cultura. É esse órgão o responsável pela organização que dará suporte para ocorrer o fenômeno no espaço material do Parque Ambiental. É através das leis e normas que há a possibilidade da criação da atmosfera de envolvimento do fenômeno estudado. É o poder público que lança os editais de seleção dos músicos, que direciona a verba para o pagamento de cachês, que entra em contato com os músicos de fora, é o responsável pela montagem e desmontagem da estrutura do palco, iluminação e som, é o responsável pela escolha do local e as datas disponíveis, bem como é responsável pela segurança dos indivíduos participantes. Como explica Fernando Durante presidente da Fundação Municipal de Cultura:

\begin{abstract}
Ocorre ali por vários fatores: primeiro porque é um lugar central, de fácil acesso, o terminal é ali, é muito fácil chegar no Parque Ambiental pelo terminal, as pessoas do centro podem ir a pé, tem todo um esquema de segurança já implantado com câmeras de vigilância, Guarda Municipal, há um posto da Polícia Militar do lado também, isso tudo são fatores que analisamos para podermos desenvolver um evento, porque é preciso pensar em todos esses fatores: o fator trânsito; o fator segurança; fator alvará; tem vários e vários. É um processo que necessita mandar solicitação e informação para polícia militar e civil, para o Juizado, enfim, toda essa parte legal precisa ser feita, ainda tem a questão dos bombeiros e tudo mais. Esses são fatores que influenciam por isso que realizar naquele espaço é mais fácil. Primeiro por ser um local central e qualquer pessoa pode vir, gratuito, por ter pontos de ônibus, tem muitas pessoas que saem do trabalho e passam no Sexta, depois pegam o ônibus para ir para casa, tem as paradas para Uber e outros aplicativos que facilitam ir e vir. (Entrevistado Fernando Durante, 2019).
\end{abstract}

Por fim, a vivência no espaço dos eventos musicais envolve tanto a imaginação e simbolismos criados pelo público, pelos músicos e também o poder público. Esse é o espaço vivido elencado por Lefebvre, é nesse espaço que se nota a vivência das pessoas em relação ao fenômeno estudado, quando essas pessoas afirmam que durante os eventos fazem amizades, se divertem, conhecem pessoas, tem afetos e desafetos; que os músicos dizem sentir uma energia do público enquanto estão no palco, sentir o reconhecimento do seu trabalho; quando os membros da Fundação afirmam que realizar esses eventos nesses moldes é importante para eles por sentirem através do retorno da população que estão fazendo um bom trabalho, tudo isso é sentido no espaço inicialmente percebido, depois concebido e enfim, vivido.

$\begin{array}{llllll}\text { Caminhos de Geografia } & \text { Uberlândia-MG } & \text { v. 22, n. } 83 & \text { out./2021 } & \text { p. 31-46 } & \text { Página } 43\end{array}$


Como afirma Lefebvre, não é possível dar maior importância de uma percepção de um espaço em detrimento do outro. Isso é notável no fenômeno estudado, o espaço físico de ocorrência dos eventos, as normatizações da ocorrência dos eventos e a vivência dos indivíduos entram em harmonia, não aparece em nenhum momento uma dimensão que se sobressaia à outra, pode-se pensar que se não fosse aquele local, naquelas normas e com aquele público, provavelmente o desfecho de ocorrência do fenômeno seria completamente diferente, o que demandaria outra possibilidade de observação e consequentemente as dimensões espaciais apresentadas por Lefebvre não se aplicariam.

\section{CONSIDERAÇÕES FINAIS}

São vários os fatores que contribuem para o sucesso dos eventos (ANDRADE, 2017), cita-se: o local de ocorrência - Parque Ambiental Governador Manoel Ribas - espaço público aberto e gratuito, localizado no centro urbano da cidade, próximo a bancos, shoppings, terminal de transporte público e comércio em geral, atualmente o local está bem arborizado e relativamente seguro já que possui um posto fixo da polícia militar; o fator diversidade musical, tanto o "Sexta às Seis", como o Festival são abertos a todos os estilos musicais desde o pop ao heavy metal; os dois eventos são inteiramente gratuitos; em nenhum dos dois há restrições de idade, possibilitando a participação desde crianças a idosos; e por fim, o incentivo aos músicos locais, escolhendo-os através de processos seletivos com pagamentos de cachês aos selecionados.

Além da diversidade cultural, aponta-se a diversidade do público participante: os dois eventos conseguem reunir no mesmo espaço do Parque Ambiental pessoas com características, gostos, ideologias, classes sociais e idades diferentes, ampliando o convívio social, o fortalecimento de laços afetivos, movimentação e apropriação do espaço público, e consequentemente, a troca de experiências. Esses eventos e festivais locais apresentam relevante importância não apenas pelo número volumoso de pessoas alcançadas e capital movimentado, mas pelo significado cultural, social e experiencial que permitem aos moradores e aos músicos locais se sentirem agentes produtores da cultura local e, ao poder público, permite efetivar através desses eventos e festivais, políticas públicas culturais.

De acordo com as falas dos respondentes ao questionário, as experiências vividas durante os eventos vão desde emoções sentidas com determinadas canções; lembranças e memórias de fatos vividos em anos anteriores; conquista de afetos e desafetos; conhecer artistas e bandas diferentes, muitas vezes da própria cidade; o reencontro com pessoas queridas; e o vivenciar e participar ativamente do fazer cultural da cidade. Todos os apontamentos demonstraram que os participantes vivem experiências importantes e inesquecíveis durante os eventos "Sexta às Seis" e Festival de Música. Do mesmo modo, para os músicos locais que tiveram a oportunidade de subir nos palcos dos eventos, a experiência foi gratificante pelo reconhecimento de seus trabalhos, pela energia e boa recepção do público e principalmente ser reconhecidos e incentivados pelo poder público local.

Evidenciou-se que os componentes do fenômeno estudado (evento musical, espaço público, política cultural) tem uma conexão muito grande, de modo que quando um deles falta, o fenômeno possivelmente deixa de existir. Os eventos musicais por si só, sem o incentivo e organização do poder público e deixando de ocorrer em espaço público aberto e gratuito, não teriam o sucesso que tem hoje. Isso é visível em outros eventos musicais que ocorrem na cidade, patrocinados por empresas privadas e com cobranças de entradas e em locais fechados, restringindo a diversidade e acessibilidade do público. Além disso, existem vários espaços públicos abertos e gratuitos no perímetro de Ponta Grossa que, sem uma atividade cultural como eventos musicais, são esquecidos tanto pela população, como pelo poder público: eles existem, mas não são utilizados. Por fim, políticas públicas culturais existentes, mas que ficam apenas no papel, não têm serventia nem para os governantes, muito menos para a população. É preciso que essas políticas sejam ativas e divulgadas, que as pessoas tenham conhecimento de sua existência, bem como saibam onde estão sendo aplicadas, além disso é necessário que o Poder Público pesquise e busque saber os desejos da sociedade para o uso dos espaços púbicos.

Finalmente, conclui-se que o direito à cidade vai além do direito e liberdade individual, já que depende do exercício do poder coletivo, e está estritamente relacionado ao tipo de cidade que queremos, com os tipos de laços e relações que desejamos ter uns com os outros, sendo assim, através dessa pesquisa foi possível notar que a cidade que os pontagrossenses e visitantes querem é uma cidade onde a cultura tenha cada vez mais espaço para se expressar de forma livre e

$\begin{array}{llllll}\text { Caminhos de Geografia } & \text { Uberlândia-MG } & \text { v. 22, n. } 83 & \text { out./2021 } & \text { p. 31-46 } & \text { Página } 44\end{array}$


diversificada com o apoio do poder público, como afirma Harvey (2012, p. 74): "a liberdade de construir e reconstruir a cidade e a nós mesmos é, como procuro argumentar, um dos mais preciosos e negligenciados direitos humanos".

\section{AGRADECIMENTOS}

Cabe destacar o agradecimento a Coordenação de Aperfeiçoamento de Pessoal de Nível SuperiorCAPES- pela concessão de bolsa de mestrado nos anos de 2018 a 2020.

\section{REFERÊNCIAS}

ANDRADE, Adriana Aparecida de. Música em espaços públicos: Projeto cultural/musical "Sexta às Seis", Ponta Grossa-PR. 2017. Trabalho de Conclusão de Curso. Curso de Licenciatura em Geografia, Universidade Estadual de Ponta Grossa, 2017.

, Adriana Aparecida de. Editais culturais lançados pela Fundação Municipal de Cultura de Ponta Grossa-PR durante o ano de 2018 e o direito à cidade. III Simpósio Internacional Interdisciplinar em Ciências Sociais Aplicadas: Democracia e Direitos Humanos, Universidade Estadual de Ponta Grossa (UEPG), 2018. Disponível em:https://drive.google.com/file/d/1aKGExtnPdsar7ZtIRKMO4PxdtEbgi7Ta/view

, Adriana Aparecida de. Música em espaços públicos: estudo sobre eventos musicais na área central da cidade de Ponta Grossa - PR. Dissertação de Mestrado em Gestão do Território, Universidade Estadual de Ponta Grossa, 2020.

BAUER, M.W; GASKELL, G. Pesquisa qualitativa com texto, imagem e som. 2ªed. Petrópolis, Vozes, 2003.

BRASIL. Constituição (1988). Constituição da República Federativa do Brasil. Brasília, DF: Senado Federal: Centro Gráfico, 1988, art 215.

CULTURA PLURAL. Sexta às Seis incentiva a produção local. Disponível em: $<$ https://culturaplural.sites.uepg.br/?p=1821> Acesso em 4 de janeiro de 2020.

CULTURA, Fundação Municipal de. Disponível em: <http://www.pontagrossa.pr.gov.br/fmc> Acesso em 4 de janeiro de 2020.

CULTURA, Ministério da Cidadania, Secretária de. Lei do Plano: LEI № 12.343, DE 2 DE DEZEMBRO DE 2010. Disponível em: <http://pnc.cultura.gov.br/lei-do-plano/> Acesso em 4 de janeiro de 2020.

CULTURA, Plano Nacional de. LEI № 12.343, DE 2 DE DEZEMBRO DE 2010. Institui o Plano Nacional de Cultura de Ponta Grossa, e dá outras providências. Disponível em: < http://pnc.cultura.gov.br/lei-do-plano/> Acesso em 28 de dezembro de 2019.

CULTURAL, Conexão. Guia do espaço público. Proac SP, São Paulo, ed. 2ª , 2016.

DARODA, Raquel Ferreira. As novas tecnologias e o espaço público da cidade contemporânea. Dissertação (mestrado) Universidade Federal do Rio Grande do Sul, Faculdade de Arquitetura, Programa de Pós-Graduação Planejamento Urbano e Regional, Porto Alegre, 2012.

GOMES, Paulo Cesar da Costa. A condição urbana: ensaios de geopolítica da cidade. Rio de Janeiro. Bertrand Brasil, 2002.

HARVEY, David. O direito à cidade. Lutas Sociais, São Paulo, n.29, p.73-89, jul./dez.2012. Disponível em:< http://docplayer.com.br/10278885-O-direito-a-cidade-david-harvey.html> Acesso em 16 de janeiro de 2020.

HERSCHMANN, M. Indústria da Música em Transição. São Paulo: Estação das Letras e das Cores, 2010, v.1.

LAKATOS, E. M.; MARCONI, M. A. de. Fundamentos de Metodologia Cientifica. 5. ed. São Paulo: Atlas, 2003 
LEFEBVRE, Henri. A produção do espaço. Trad. Doralice Barros Pereira e Sérgio Martins (do original: La production de l'espace. $4^{\circ}$ éd. Paris: Éditions Anthropos, 2000). Primeira versão: início fev.2006.

, Henri. O direito à cidade. São Paulo: Moraes, 2001.

LOBODA, Carlos Roberto. Práticas socioespaciais e espaços públicos em Guarapuava-PR. Tese de doutorado Produção do Espaço Geográfico, da Faculdade de Ciências e Tecnologia de Presidente Prudente/SP, Universidade Estadual Paulista, 2008.

MAFFESOLI, Michel. O ritmo da vida. Rio de Janeiro: Record, 2007.

PONTA GROSSA, Festival de música começa nesta sexta com mais de $\mathbf{3 0}$ atrações nacionais e locais. Disponível: <http://www.pontagrossa.pr.gov.br/node/32511> Acesso em 13 de julho de 2019.

PONTA GROSSA, LEI № 13.026, DE DEZOITO DE DEZEMBRO DE 2017. Institui o Plano Municipal de Cultura de Ponta Grossa, e dá outras providências. Disponível em: $<$ https://leismunicipais.com.br/a/pr/p/ponta-grossa/leiordinaria/2017/1302/13026/lei-ordinaria-n-130262017-institui-o-plano-municipal-decultura-de-ponta-grossa-e-da-outras-providencias > Acesso em 11 de novembro de 2018.

SANTOS, Milton. A Natureza do Espaço: Técnica e Tempo, Razão e Emoção. 4aㅡ edição. São Paulo: Editora da Universidade de São Paulo, 2006.

SCHOENHERR, Rafael. A imagem da música no espaço público em Ponta Grossa (PR) de 2010 a 2014: implicações geográficas do fotojornalismo cultural. Tese de doutorado apresentada ao Programa de Pós-Graduação em Geografia da Universidade Estadual de Ponta Grossa, 2017.

SERPA, Angelo. Espaço público e acessibilidade: notas para uma abordagem geográfica. GEOUSP Espaço e Tempo, São Paulo, № 15, pp. 21 37, 2004.

, Angelo. $O$ espaço público na cidade contemporânea. São Paulo. Editora Contexto, 2007.

SETTON, Maria da Graça Jacintho. A teoria do habitus em Pierre Bourdieu: uma leitura contemporânea. Revista Brasileira de Educação Maio/Jun/Jul/Ago 2002 № 20. https://doi.org/10.1590/S1413-24782002000200005

SOBARZO, Oscar. A produção do espaço público: da dominação a apropriação. GEOUSP- Espaço e Tempo, São Paulo, № 19, pp 93-111, 2006. https://doi.org/10.11606/issn.21790892.geousp.2006.73992

SOUZA, Felipe Silveira de. O espaço público contemporâneo: A complexidade vista a partir de parques urbanos de Porto Alegre. Dissertação de mestrado apresentada ao Programa de PósGraduação em Geografia da Universidade Federal do Rio Grande do Sul, Porto Alegre, 2008.

TORRES, Marcos Alberto. Os sons que unem: a paisagem sonora religiosa e a identidade religiosa. Tese de doutorado apresentada ao Programa de Pós-Graduação em Geografia da Universidade Federal do Paraná, Curitiba,2014.

VALVERDE, Rodrigo Ramos Hospodar Felippe. Por uma perspectiva geográfica dos espaços públicos: repensando a espacialidade da dimensão social. ESPAÇO E CULTURA, UERJ, RJ, №. 22, P. 67-78, JAN./DEZ. DE 2007.

Recebido em: 13/07/2020

Aceito para publicação em: 24/05/2021 